del agua y, a partir de ello, recomiendan diseñar programas de desarrollo que tomen en cuenta a las personas. Pero, ¿cómo conseguir este objetivo?

Indudablemente, el estudio de las prácticas y las representaciones sociales de los habitantes de una ciudad en torno al recurso hídrico, propósito de este libro, nos permitirá conocer los significados de este vital líquido en el pasado y en el presente, condición indispensable para diseñar políticas públicas con un verdadero sentido humano que respeten una diversidad de culturas sustentables del agua.

Ciudad de México, noviembre de 2009.

Graciela de Garay INSTITUTO MORA

John Mraz, Looking for Mexico: Modern Visual Culture and National Identity, Duke University Press, Estados Unidos, 2009, $343 \mathrm{pp}$.

En la antesala del bicentenario de la independencia de México, el centenario de la revolución mexicana y las anunciadas magnas celebraciones al respecto, aparece el libro Looking for Mexico, de John Mraz. El libro se desarrolla entre la advertencia del autor sobre la subjetividad del escrito y la multitud de referencias bibliográficas que acompañan casi cada párrafo; Mraz acepta que su reflexión se basa en su experiencia en lo que llama cultura visual mexicana y a la vez sustenta sus opiniones en estudios realizados por diversos especialistas, lo que convierte a este texto en una guía sobre cómo se ha estudiado lo visual de México. Habría que dete- nerse en esto último, pues la mayoría de las obras citadas y referenciadas son de carácter especializado y muchas de ellas monotemáticas, pero que en su conjunto (agrupadas por Mraz) ofrecen una panorámica del trabajo de investigación en el país y sobre él.

Es importante tomar en cuenta que este autor escribe para un público estadunidense -como él mismo declara en la introducción-, por lo que en el texto se resumen algunas cuestiones sobre la historia política de México con el fin de ofrecer un contexto mínimo para las interpretaciones que realiza. Lo que obtiene es un estudio general sobre la histórica relación entre la elaboración de imágenes y el mundo que estas interpretan y crean, lo que lo convierte en una obra interesante para lectores ávidos de participar en la reflexión, no sólo estadunidenses. Así, el título Looking for Mexico delata el ejercicio personal de comprensión de un país a la vez que revela la forma en que se lleva a cabo la búsqueda de tal conocimiento: mirando.

El autor, consciente de lo abstracto de la reflexión sobre lo visual, decide apuntar sobre el asunto de la identidad. Puesto que esta es construida y reconstruida aparece así como un ejercicio para entender las transformaciones de su interpretación y representación. Aun siendo así la cuestión de la identidad concepto tan amplio, Mraz dirige la reflexión hacia la mexicanidad através de representaciones explícitas, por ejemplo, en las obras de Hugo Brehme, Tina Modotti, Manuel Álvarez Bravo, Luis Márquez, Emilio "el Indio" Fernández y Gabriel Figueroa, entre otros. Entendiendo la identidad en relación con el ser de lo mexicano explorará las construcciones, conscientes o inconscientes, de los 
hacedores de imágenes. Para Mraz el asunto puede bifurcarse en dos visiones: lo pintoresco en contraposición a lo antipintoresco. En la primera, lo mexicano es producto de la naturaleza y de los vestigios dejados por las culturas precolombinas, la colonia y el subdesarrollo; la identidad es en esencia hecha y dada por siempre. A ello se opondrá lo mexicano como producto de experiencias históricas, lo antipintoresco.

No se trata tampoco de una propuesta sobre la imagen en general, el autor es claro al respecto; se trata de pensar imagen, identidad, mexicanidad, lo pintoresco y lo antipintoresco de la cultura visual moderna, la cual Mraz define como aquella que se produce por imágenes y sonidos técnicos: la fotografía y el cine son los medios en los que se detendrá en este libro, lo cual se justifica bajo el supuesto de que la credibilidad de la reproducción fotográfica es un elemento primordial de la modernidad a partir de la invención de la fotografía en 1839, pues la gente asigna desde entonces un valor de verdad mayor al de otras expresiones visuales como la pintura, el grabado o el dibujo, lo que cambió la relación de las representaciones con lo real.

La cultura visual moderna en México empieza con un suceso definitivo en la identidad nacional: la invasión y ocupación de México de 1846 a 1848 como el primer conflicto en el mundo en ser documentado en litografías y fotografías. De esta manera se irán configurando fotografías, filmes, revistas e historias ilustradas en un conjunto como un agente poderoso de construcción de la identidad nacional de México desde 1867, siendo dominante en la década de 1920. Por ello el interés en presentar un libro que analice esos soportes.
La propuesta de análisis de este libro se estructura en cinco capítulos: "War, Portraits, Mexican Types, and Porfirian Progress (1847-1910)"; "Revolution and Culture (1910-1940)"; "Cinema and Celebrities in the Golden Age"; "Illustrated Magazines, Photojournalism, and Historia Gráfica (1940-1968)", y "New Ocular Cultures and the Old Battle to Visualize the Past and Present (1968-2007)". No se trata de un estudio cronológico; las divisiones se caracterizan por presentar etapas de la historia de México agrupadas por las transformaciones en la forma en que se producen las imágenes. Sin embargo, no se puede entender como un proceso de desarrollo, lo que se pone en evidencia es la repetición de patrones de producción y la razón de ser de nuevas producciones de imágenes en relación con una oposición hacia lo ya hecho, pero también como respuesta a los correspondientes contextos políticos y sociales. $\mathrm{Y}$ lo que es más interesante, tratar de entenderlo como resultado de contextos de producción donde desempeñan un papel muy importante los emisores del discurso más allá de la autoría o de la figura solitaria del fotógrafo, es decir, de las instituciones y/o grupos políticos alrededor de los autores que ejercen su voluntad de producir imágenes que comuniquen una $u$ otra visión de lo mexicano. Por ejemplo, la relación del gobierno de Porfirio Díaz y el fotógrafo Guillermo Kahlo, en el cual se evidencia el interés oficial en poner lo hispánico más que lo indio como sentido esencial de la nación.

México se presenta en este libro como un país muy fotografiado por extranjeros. Mraz apunta a pensar en la forma en que son financiados y los intereses que motivan los viajes y el bagaje cultural de los 
visitantes. Por ejemplo, los franceses Desiré Charnay y Francois Aubert, ambos traídos en misiones imperiales, caracterizan a los tempranos hacedores de imágenes. También se estudian los fotógrafos invitados por el porfiriato, como C. B. Waite y William Henry Jackson. ¿Por qué fotografían México, qué fotografían y cómo lo hacen?, son preguntas que nos dirigen al camino de pensar cómo ha sido construido lo mexicano desde ese punto de vista; se trata de abordar la identidad nacional pensada desde la representación extranjera en el siglo XIX.

Mraz propone estudiar las imágenes en lugar de buscar sólo aquellas que representen momentos "históricos", lo que finalmente será pensar la idea y posibilidad de que las representaciones transforman a las sociedades. Un caso que sirve de eje al libro es el de Agustín Víctor Casasola y el archivo Casasola y su influencia en la percepción que se tiene de la historia nacional y la revolución en la formación de la identidad contemporánea, lo que en el fondo es una propuesta para pensar los medios de difusión de las imágenes y el contexto en que las fotografías son producidas para medios de difusión masiva, como lo son los periódicos. Agustín Víctor Casasola comenzó vendiendo sus fotos (y las de otros fotógrafos) para periódicos como El Universal y El Imparcial, el periódico por antonomasia del porfiriato: moderno, comercial y conservador.

El caso del Archivo Casasola se analiza de forma constante en el texto; no se trata sólo de un recuento cronológico de la vida de las imágenes que se han ido agrupando en este archivo. Mraz describe insistentemente la forma en que estas fotografías han pasado por la orfandad para mezclarse en el universo de la construcción de la historia de México y la identidad nacional, llamada Archivo Casasola; el asunto es abordado incisivamente al punto de denunciar la falta de estudios profundos sobre el archivo en sí. La forma en que se seleccionan las imágenes en las publicaciones del Archivo Casasola se acompañan de textos de algún pariente Casasola y se caracterizan por la falta de participación de especialistas historiadores, lo que por supuesto llama la atención para repensar su papel en la configuración de la cultura visual en México hasta llegar a los trabajos que ha hecho Enrique Krauze y las publicaciones de Clío y Televisa con este archivo.

Mraz expone algunas constantes partiendo de la revolución mexicana como hecho fundacional de la construcción de lo mexicano y un concepto clave para abordarlo es el de great man, líderes con nombre y apellido con alta capacidad de toma de decisiones; las historias gráficas desde el siglo XIX presentan la historia de México como resultado de ello, la historia de México como producto del trabajo de un puñado de grandes hombres. El asunto de las cartes de visite ${ }^{1}$ (tarjetas de visita) sirve para explorar las representaciones de identidad en relación al inicio de las reproducciones del great man, comenzando por las imágenes de Benito Juárez en tarjetas de visita. Otro uso de estas últimas son las de Cruces y Campa, llamadas Tipos

\footnotetext{
${ }^{1}$ Tipo de fotografía pequeña patentada por el fotógrafo francés André Adolphe Eugène Disdéri en 1854. Generalmente se trataba de una impresión en albúmina; el tamaño de un carte de visite es de 2.125 por 3.5 pulgadas montada en un soporte rígido de 2.5 por 4 pulgadas, aproximadamente. Fue el primer tipo de fotografía en masificarse.
} 
mexicanos, las cuales privilegian la representación de coloridos personajes callejeros en lugar de los grandes grupos de trabajadores en la búsqueda de la diferencia en la construcción de estereotipos que representarían lo mexicano.

Así, el autor comienza por poner sobre la mesa lo mexicano, como la belleza exótica y la creación de un "vocabulario visual" de la mexicanidad que presentó Hugo Brehme. La visión de Brehme es socialmente miope y retrógrada; es decir, que lo pintoresco es una imagen idílica de lo que se cree representativo de lo mexicano, lo que se opone a la representación de la mexicanidad como lo diverso y complejo, que para Mraz se ejemplifica con la pareja de Edward Weston y Tina Modotti, quienes aluden en vez de presentar. Posteriormente se aborda el giro de la revolución mexicana en la década de 1940 hacia la derecha en el proceso de institucionalización, es entonces cuando la historia es presentada como la reducción a estereotipos, el nacionalismo promovido por el PRI como determinante para buscar la identidad como una disculpa de la desigualdad.

El análisis incluye a las estrellas de cine como patrones a seguir en cuanto se crea alrededor de ellos un universo en el que no hay diferencia entre el personaje representado y la persona que actúa. Las estrellas de cine ocuparon las páginas centrales de las revistas ilustradas entre mediados de 1930 y hasta mediados de la década de 1950, tomando el lugar que ocupaban los daguerrotipos, las tarjetas de visita y las postales. Aparecen figuras como María Félix y Dolores del Río, pero también los tipos populares: "Cantinflas" como personaje que representa la adaptación del campesino a lo urbano en oposición a
"Tintán" como el pachuco. La transculturalidad en este último caso se opone a la visión tradicional de lo mexicano. Finalmente, las representaciones de la vida de Frida Kahlo -Felipe Cazals con Frida, naturaleza viva (1983) y Julie Taymor con Frida (2003); la primera protagonizada por Ofelia Medina y la segunda por Salma Hayek- sirven de ejercicio para pensar lo mexicano en relación con lo extranjero y lo diverso de la identidad en relación con la influencia del país del norte.

Posteriormente, Mraz también reflexiona sobre el movimiento estudiantil como línea divisoria en la historia mexicana y la construcción de identidad. Las representaciones del 1968 mexicano realizadas por Leobardo López (El grito, 1969), Felipe Cazals (Canoa, 1975), y Jorge Fons (Rojo amanecer, 1989) son un puente para repensar las construcciones de lo mexicano. El medio a analizar a partir de esta época se encontrará en la prensa como critica de la realidad social del país, una reflexión sobre la pérdida de credibilidad del fotoperiodismo y en general de la imagen a raíz de la digitalización de los medios. ${ }^{2} \mathrm{Se}$ aborda el papel que desempeñaron las revistas impresas en la construcción de lo mexicano, sobre todo el fotoperiodismo y las imágenes que ofrecían en el contexto del México de la desigualdad social y el gobierno del Partido de la Revolución Institucional. Las revistas Hoy, Mañana, Siempre! y Presente son experiencias de presentación de la imagen como protesta y como reproducción del discurso oficial o

${ }^{2}$ John Mraz, ¿Qué tiene de documental la fotografía?, Revista Zonezero, trad. Ari Bartra. Véanse $<\mathrm{http} / / 200.2 .12 .132 / \mathrm{SVI} / \mathrm{images} /$ stories/fotoperiodis $\mathrm{mo} / \mathrm{pdf} / \mathrm{mraz}$ 1.pdf>, y <http://www.zonezero.com/ magazine/articles/mraz/mraz01sp.html>. 
como oposición al mismo (tal es el caso de esta última).

El trabajo de Mraz se detiene especialmente en los fotorreporteros Nacho López, Héctor García y los Hermanos Mayo, para abordar la búsqueda de lo mexicano en la cotidianidad del ser común y corriente, la identidad forjada por gente haciendo comúnmente lo que a la vez los significa. Las noticias (fotorreportajes) así son convertidas en arte que juega con el discurso de la apertura democrática del PRI.

Finalmente, Mraz llega a ver la identidad como construcción en donde lo visual es parte de la interpretación no sólo de quien estudia la historia pasada sino que en sí es una propuesta de análisis de la realidad nacional. John Mraz rescata una idea de Enrique Florescano que podemos ampliar a un periodo histórico más amplio,

la revolución no es sólo los hechos ocurridos entre 1910 y 1917 , o entre 1910 y 1920, o entre 1910 y 1940; es también el conjunto de proyecciones, símbolos, evocaciones, imágenes y mitos que los participantes, interpretes y herederos forjan y construyen alrededor del evento.

Por ello, el contexto de producción, las condiciones específicas de desarrollo de la tecnología para la producción de imágenes, la elección de lo fotografiado, filmado y/o escrito por el realizador, las influencias que dirigen al discurso y por supuesto las formas de difusión de la obra son elementos que dotan de sentido a la producción de imágenes y al mundo que estas transforman. Lo que el estudioso de ellas deberá no sólo considerar sino entretejer en una interpretación de lo social. INSTITUTO MORA 


\section{Normas para los colaboradores}

Secuencia considera para su publicación trabajos que sean el resultado de una investigación original y constituyan una aportación relevante al conocimiento de su área, que no hayan aparecido o estén por aparecer en otras publicaciones y cumplan con las siguientes especificaciones.

\section{Características generales DE LOS MANUSCRITOS}

Los trabajos (artículos y reseñas) deberán ser escritos a doble espacio, con letra Times New Roman de 12 puntos (notas al pie en 10 puntos) en versión Word o compatible. En el caso de los artículos, la extensión puede variar entre 25 y 40 cuartillas; los ensayos bibliográficos (valoración crítica de varios textos de reciente aparición) tendrán una extensión máxima de 20 y las reseñas de siete cuartillas. Los ensayos bibliográficos y las reseñas incluirán las referencias completas de los libros comentados.

Los trabajos deberán ser enviados ya sea por correo electrónico (en archivo adjunto) a $<$ secuencia@institutomora.edu.mx>, en disquette de 3.5 " debidamente rotulado, o en su versión impresa.

\section{INFORMACIÓN QUE DEBEN CONTENER LOS MANUSCRITOS}

- Nombre y adscripción institucional del autor.

- Datos curriculares (diez líneas como máximo).

- Un resumen en el que se destaquen las aportaciones y los aspectos relevantes del trabajo (máximo diez líneas).

- Palabras clave del texto (entre cinco y diez).

- Domicilio, número telefónico, de fax y dirección de correo electrónico.

\section{NOTAS AL PIE DE PÁGINA}

Las notas se indicarán con números arábigos y volados, en orden consecutivo, y aparecerán al pie de página. Los datos se registrarán de acuerdo con los ejemplos que se presentan a continuación, tomando en cuenta las siguientes indicaciones de carácter general: se indicará el primer apellido del autor, la primera palabra del título en cursiva o subrayado si es libro, o entre comillas si es artículo (excluyendo artículos y preposiciones), el año de edición, volumen y tomo y número de páginas (utilizando las abreviaturas vol., t. y p., en singular, o vols. tt. y pp., en plural); el signo de puntuación que se empleará para separar los datos será la coma. Se usará ibid. cuando el mismo libro o artículo se cita una o varias veces consecutivas. No se empleará op. cit. en citas repetidas.

\section{Ejemplos}

Cita consecutiva:

Zamacois, Historia, 1882, t. XVIII, p. 493. Ibid., p. 576.

Citas de un mismo texto sin ser consecutivas: Zamacois, Historia, 1882, t. XVIII, p. 493.

Torre, "Niceto", 1996, p. 559.

Correa, "Francisco", 1996, p. 201.

Zamacois, Historia, 1882, t. XviII, p. 345.

Libro:

Hunt, Ideology, 1987, pp. 3-17.

Capítulo de libro colectivo:

Terrazas, "Relación", 1998, p. 347. 